УДК $821.111(73)$

\title{
ФІЗИЧНИЙ ТА УЯВНИЙ ПРОСТІР ГАРЛЕМА ПОЧАТКУ ХХ СТОЛІТТЯ
}

\section{Марія Мирославівна Шимчишин}

\author{
https://orcid.org/0000-0003-4980-3296 \\ mshymchyshyn@yahoo.com \\ докторка філологічних наук, професорка, завідувачка кафедри теорії та історії світової \\ літератури імені професора В. І. Фесенко, \\ Київський національний лінгвістичний університет
}

\begin{abstract}
Анотація. На початку ХХ століття формування нової афро-американської суб'єктності вимагало ї̈ опросторовлення на фізичному та уявному рівнях. Гарлем - столиия Нового Негра - стала втіленням расового простору та місцем локалізації расового Іншого. Варто зазначити, щзо існував суттєвий розрив між реальним Гарлемом і тим, який, з одного боку, уявляли бідні мігранти з Півдня, а з другого - з тим, який оприявлений у художньому дискурсі Гарлемського ренесансу. У статті розкрито шляхи творення расового простору, а також стверджується про його обмеженість класовою складовою. Відтак авторка доходить висновку, щзо расовий простір не був однозначним і гомогенним, в ньому існували напруження класового характеру. Крім того, Гарлем в уяві бідних новоприбульців із Півдня контрастував із реальним Гарлемом, де реалї життя примушували чорношкірих зрікатися своїх надій.
\end{abstract}

Ключові слова: раса; Гарлем; простір; клас; геокритика.

Постановка проблеми. На початку XX століття Гарлем став столицею Нового Негра і територією, де формувалася нова суб'єктність чорношкірих американців. Цей новий тип расового простору приваблював темношкірих не лише зі США, а також з інших країн, у ньому відбувалася гомогенізація новоприбульців у нову урбаністичну колективність. Територія Гарлема швидко розширювалася у зв'язку зі стрімким збільшенням населення. Кері Вінц зауважує, що ще в 1920-х роках «Гарлем обмежувався кордонами від 130-ї вулиці до 145-ї і від П'ятої авеню до Восьмої, де проживало 73 тисячі чорношкірих, а вже у 1930 році Гарлем розширився десять блоків на північ до 155-ї вулиці та на південь до 115-ї вулиці, його межі пролягали від річки Гарлем до Амстердам авеню, і там уже мешкало приблизно 164 тисячі чорношкірих» [6, p. 34].

В американській колективній свідомості Чорний Мангеттен звужений до відомого висловлювання Алена Локка «столиці Нового негра», що мала відіграти таку ж роль, як Дублін для Нової Ірландії чи Прага для Нової Чехословаччини. У цьому висловлюванні маємо чітку інтенцію до «відтворення тільки однієї риси в об' єкті імітації» [2, с. 302], тобто індивідуалізацію Однак уважне прочитання художніх текстів того періоду дає нам дещо інше уявлення про столицю Нового Негра. Найперше вражає те, що поза увагою залишилася класова стратифікація цього расового простору. Головним чином через те, що афро-американці традиційно вважалися приналежними лише до одного класу - бідних робітників. Хоча середній i багатий класи також існували. 3 цього приводу Франклін Фрейзер у статті «La Bourgeoisie Noire» стверджував, що «негрів як групу відносять до гомогенного робочого класу. У той час, як ця група надзвичайно різноманітна, з таким же відсотком широких інтересів, як і група білих американців» [4, p. 137]. Таким чином існування середнього класу цілком нівелювалося у домінантному соціологічному чи культурно-історичному дискурсах. Іншими словами, можемо сказати, що класова ідентичність нівелювалася на користь расової. На порядку денному того часу було формування однотипної расової ідентичності та іiї маркерів, а ін'єкція у цей процес класового складника ускладнювала процес побудови расової колективності. Доречно тут процитувати слова А. Ріда, який пише: «Головна проблема в тому, що білі не хочуть подивитися у вічі реальності і визнати, що політичне життя чорношкірих складне, напружене та неоднозначне. Загалом, вони просто не бачать політичних відмінностей серед чорношкірого 
населення. Вони не розуміють того, що чорношкірі пов'язані із соціальними, політичними та економічними інституціями по-різному, і що ці різноманітні зв'язки та відносини визначають інтереси та ідеологічні вподобання чорношкірих так само, як і білих американців» [12, p. 72].

Виклад основного матеріалу. Залучення стратегій геокритики до аналізу фікційних репрезентацій Гарлема сприятиме не лише увиразненню того, яке значення має простір для формування колективності, у нашому випадку расової колективності, але і вербалізувати негомогенність та стратифікацію расового простору, а відтак i проблематизувати ідею цілісності расової колективності. Рух від реального простору до творення фікційних локусів дає можливість осягнути, які саме елементи реального фізичного простору актуалізовано в художній літературі, а які навпаки відсунуто на маргінес. У цьому випадку маємо перетини фікційного опису місця із ідеологічною настановою часу.

Аспект класового поділу простору залишився неосмисленим у контексті Гарлемського ренесансу. Адже традиційно Гарлем був локусом расового Іншого та расового поділу території Нью-Йорка, що давало можливість управляти і контролювати життя великих мас людей, які прибували з Півдня, а також з Південної Америки. Дональд Мітчелл у роздумах про простір та расу доходить висновку, що «зосередженість на географії раси демонструє те, як раса, подібно до культури, може стати чимось дуже реальним внаслідок низки просторових стратегій, що розроблені для того, аби підтвердити факт існування раси, якщо не в природі, то, принаймні, в суспільстві» [10, р. 250]. Опросторовлення афро-американців у кордонах Верхнього Мангеттену допомогло локалізувати расу та надати їй певне місце у просторі. Таке розмежування фізичного локусу створювало перепони для змішування людей різних рас та сприяло формуванню того, що Д. Мітчелл називає «географічним привілеєм» [дет. див. 9], або просторовою формою репродукції нерівності. Для білих американців створення географії раси не лише підтримувало практику расової сегрегації, а й було способом демонстрації влади білих щодо розподілу теритоpii. У цьому контексті варто згадати твердження Анрі Лефевра про те, що простір це - політичний інструмент контролю над людьми: «Держава використовує простір для того, щоб демонструвати свій контроль над місцями, упевнитися в існу- ванні ієрархії, гомогенності цілого та сегрегації частин. Таким чином простір адміністративно керований та перебуває під контролем поліції» [9, p. 188]. Через демаркацію простору білі американці могли дистанціюватися від чорношкірих, у той час, коли держава могла тримати під поліцейським наглядом райони 3 новоприбульцями.

Варто загадати, що відкрита політика поселення чорношкірих в окремо визначених районах Нью-Йорка існувала ще до періоду Великої міграції з Півдня, що розпочалася під час Першої світової війни і тривала після неї. Проте саме у 1920х роках вона стала очевидною. Від початку руху афро-американців на Північ їм дозволяли поселятися лише в певних районах. Так, від 1800-х років на Мангеттені існували окремі поселення чорношкірих. Далі між 1900 - 1910 роками афро-американці жили в районі Мангеттена під назвою Чорна Богемія, що нагадував радше гетто, поруч $з$ яким знаходилися будинки розпусти та гральні заклади.

Дискримінація чорношкірого населення проявилася із масовим переміщенням чорношкірих iз Півдня. Як зазначає Г. Гайєнз, «щойно негри поселялися у Гарлемі, як білі тут же виїжджали звідти» [7, p.117]. Реалії жорстокого протистояння між расами описані і в романі Р. Фішера «Мури Єрихону»: «Гарлем розпочинався 3 погромів. Я пам'ятаю, як підлітком боявся виходити на вулицю ввечері. То були лихі часи - зграя «пацанівфеїв» могла зловити «джига ${ }^{1} »$ та відлупцювати його, або ж зграя «джигів» могла схопити «хлопця-фея» та показати йому гнів Господній... То були веселі дні, - продовжував він. Люди тримали каструлі з їдкою кислотою на плитах і як тільки дзвонив дзвоник, бігли з нею до дверей. 3 даху свого будинку ви могли побачити, що на чотири блоки немає жодного димаря: їх усіх розібрали, а цеглу склали на вікні в передпокої, як боєприпаси» $[3$, p. 39 - 40]. Війна за територію - це завжди трагедія, що не сприяє порозумінню між расами: «тріумф чорношкірих - це трагедія білих. Ми виграли - ми виграли територію. Всі «феї» змушені були забиратися геть, дати нам дорогу, залишити нам простір. Що ж вони робили? Очевидно опиралися, а чому б і ні. Трималися за свій район, намагалися не віддати. А ми розбивали їм голови цеглою $з$ димарів та купали їх у кислоті. Що вони можуть почувати до нас?» [3, p. 42].

Дж. В. Джонсон у праці «Чорний Мангеттен» звернувся до формування простору Гарле-

1 Джиг (jig) - негр у негритянській англійській. 
ма. Автор зазначав, що «навала» чорношкірих до Мангеттена спричинила паніку серед білих, які усвідомлювали, що їхнє перебування в одному просторі із афро-американцями не лише знижує ціну на їхню нерухомість, але й принижує їхній соціальний статус. Присутність хоча б однієї родини чорношкірих, навіть якщо це були представники середнього класу, тут же змушувала білих продавати будинок і покидати район. При цьому ціни різко падали і багато чорношкірих скористалися цим [дет. див.:8, 151].

Утвердження Гарлема як расового простору відбувалося 3 допомогою економічної та символічної влади. Перший афро-американський рієлтор Філіп Пайтон, якого називали «батьком Гарлема», сильно вплинув на становлення столиці Нового Негра. Зокрема, він викуповував квартири на Верхньому Мангеттені і здавав їх в оренду чорношкірим клієнтам. Таким чином, на початку XX століття Гарлем вважався престижним районом для чорношкірої буржуазії. Згодом, потужний рух афро-американців із Півдня і їх поселення у Гарлемі зумовили конфлікт між простими, неосвіченими і бідними чорношкірими та представниками середнього класу. Останні покинули Гарлем щойно він перетворився на гетто.

Щодо символічної влади, то слід наголосити на декількох моментах iï оприявлення. Зокрема, маємо на увазі паради, які щотижня організовувалися на вулицях і які разом із традиційними недільними прогулянками вулицями утверджували владу чорношкірих у цьому конкретному просторі. Ще один тип символічної влади це - переназивання вулиць, будівель, місць. Так, будинки, що викуповували афро-американські агенції нерухомості, тут же називали на честь славетних чорношкірих. Наприклад, Філіс Вітлі, Пола Данбара чи Туссена Лувертюра.

Як видно 3 викладеного вище, фізичний простір Гарлема як територія Нового Негра формувався за допомогою економічних та символічних інструментів влади. Білі мешканці покидали i продавали за безцінь своє житло, аби не жити в одному районі із чорношкірими. Цей факт $є$ ще одним свідченням позірності політики расової толерантності на Півночі. Іншими словами, білі підтримували антирасистські погляди поки це не торкалося їхнього особистого простору. Прописування раси в Гарлемі відбувалося через апропріацію будівель, вулиць, парків та інших громадських місць. Переназивання, встановлення пам'ятників, паради - основні форми символічної влади, що утверджувала зміну власників території.

Окрім фізичного простору Гарлема необхідно взяти до уваги і його уявний образ, а саме, яким він був у свідомості нових мешканців чи тих, які мріяли потрапити у нього. Традиційно маємо конфлікт між сподіваннями і реальністю. Місто - це не лише зміна зовнішніх ознак: висотні будинки, метрополітен, натовп; це не просто можливість знайти кращі умови існування чи зреалізувати себе; для афро-американського мігранта 3 Півдня - це найперше розкріпачення та звільнення від страху тілесного покарання. Адже, як зазначає Ф. Гріффін, «Насильство як каталізатор міграції $є$ лейтмотивом у міграційних наративах афро-американських митців. I хоча причини, жертви та гнобителі постійно змінюються, оскільки історична та культурна інтерпретації обумовлені різними соціальними й політичними реаліями, принцип залишається один: у творчості чорношкірих художників та письменників систематичне насилля над чорношкірим тілом головна причина втечі 3 Півдня» [5, p. 45].

Північний локус не позбавлений дискримінаційного тиску, який переважно набирає форм морального пригнічення: труднощі знайти працю через колір шкіри, низькооплачувана чи некваліфікована робота навіть для тих, що мають добру освіту, брутальність поліції, визначені локуси для проживання та розваг. Епізоди упослідження чорношкірих на Півночі присутні в романах Гарлемського періоду. По-своєму вони деконструюють локус міста як місця свободи індивідуума.

Нормалізація поведінки та способу життя мігрантів з Півдня відповідно до звичок та манер містян була одним зі шляхів упокорення «неслухняних» тіл міських новоприбульців. Останні почували страх бути покараними через хибність своїх вчинків. «Невідповідна» поведінка могла спричинити байдужість, приниження, позбавлення посади, презирство чи зневагу з боку більшості. Наприклад, в одному з бюлетенів Міської ліги серед настанов для чорношкірих, що приїжджали 3 Півдня, були такі: не говорити голосно на вулиці чи у громадських місцях, охайно одягатися, не носити темних кашкетів, фартухів, домашнього одягу чи хатніх капців на вулиці [дет. див. 5, p. 3]. Міська мода та коди поведінки відрізняються від сільської культури. Таким чином, мігранти найперше намагаються змінити свій зовнішній вигляд на догоду смакам урбаністичної маси. Головна 
героїня роману В. Термена «Чим чорніша чорниця...» - Емма Лу — перед тим, як іти на співбесіду з роботодавцем, пригадує, що в одному 3 офісів бачила, як секретарка припудрювала блиск на обличчі перед зустріччю з начальником. Дівчина діє так само. Набуття навичок і кодів життя в місті відбувається через наслідування поведінки містян. Мігранти намагаються не відрізнятися від більшості, не демонструвати свою інакшість.

Міський локус - це простір, де новоприбулець почувається чужинщем, відірваний від свого коріння та минулого, він відчайдушно шукає своє місце в новому просторі. Втрата рідної домівки одна 3 головних причин його душевного неспокою. Часто міське помешкання описується як гнітюче, тиснуче, як тимчасова зупинка індивідуума. Втрата дому породжує у новоприбульця відчуття нестабільності та незахищеності. Легкість, з якою мігранти змінюють одне помешкання на інше, засвідчує їхню внутрішню розгубленість. Наприклад, постійна зміна квартир Еммою Лу в романі «Чим чорніша чорниця....» експлікує пошук дівчиною своєї ніші в хаосі міського буття.

Окрім змалювання міського локусу важливу роль в афро-американській літературній традиції має процес міграції переважно 3 південних чи середньозахідних провінційних містечок і навіть міст до великих урбаністичних центрів: Нью-Йорк, Чикаго. Міграційний наратив передбачає чотири основні етапи: подія, що зумовила рух героя на Північ; його початкова конфронтація 3 містом; намагання героя асимілюватися в новому місці та його опір негативним впливам міста; усвідомлення можливостей зреалізувати себе на Півночі й конструювання урбаністичної суб'єктності [дет. див. 5, 4].

У контексті афро-американського досвіду покинути Південь означало не лише позбутись нав'язливого страху перед можливим лінчування, але й втратити простір предків, расової пам'яті та історії. Водночас розрив із рідною спільнотою давав шанс нащадкам колишніх рабів будувати нове життя без нагадувань чи свідчень про ганьбу їхнього минулого. У романі В. Термена «Чим чорніша чорниця...» дід та бабуся головної героїні, мулати за походженням, вирішують покинути Південь, щоб «якнайдалі відірватися від фізичного та ментального простору батьківського дому» [13, p. 8]. Вони не бажають жити серед людей, які все ще пам'ятають про рабське минуле їхніх предків.

Велика міграція вплинула й на організацію, побут та культуру великих міст. Міські прибульці ставали не лише жертвами міського способу життя, часто вони виражали свій протест через створення власних просторів, що не контролювались владою або ж були визнані нею як екзотичний простір із правом на існування. До таких безпечних місць належали більярдні, нічні клуби, приватні помешкання зі славнозвісними вечірками (rent parties), кабаре, де підтримувалася південна культура чорношкірих, відтворювались реалії південного життя та фольклорні надбання. Такі альтернативні локуси давали мігрантам можливість протистояти урбанізації свідомості та певним чином підтримувати зв'язок із минулим. Ф. Гріффін підкреслює подвійну природу таких безпечних місць: «3 точки зору прогресу безпечні місця є такими, що живлять, зцілюють та захищають, 3 консервативної перспективи вони притлумлюють протест та ув'язнюють героя у гнітючому минулому» [5, p. 111].

Суттєві зміни відбулись і в церковній культурі. Зокрема популярним стало внесення госпел ${ }^{2}$ у церковні богослужіння, хоча тривалий час вони заперечувались північними негритянськими спільнотами як занадто емоційні та чуттєві. Таким чином церква набула статусу безпечного простору для мігрантів. Адже у ній вони мали змогу переживати ті самі релігійні ритуали, стани душевного піднесення та короткочасного заспокоєння, утіхи як і під час відвідин церковних богослужінь «вдома». Церкви допомагали новоприбульцям адаптуватися до міських реалій, розраджували їхнє розчарування. Водночас як блюз, так і госпел тривалий час заперечувались середнім класом чорношкірих, аж поки ці прояви афро-американської культури не стали предметом захоплення білих. Відтак церкви та клуби були своєрідними оазами південної культури, за якою сумували та якої потребували мігранти. У текстах афро-американських письменників такі альтернативні локуси функціонують як безпечні місця, де новоприбульці переживали психологічний катарсис. Як зазначає Ф. Гріффін: «Якщо глянути уважніше, то можемо сказати, що ці два простори, церква та танцювальний майданчик, розкривають діалектику афро-американської ідентичності: чорношкірі $є$ одночасно модерними та домодерними» [5, p. 82].

Отже, міграція до міста мала двовимірний характер. По-перше, вона змінювала свідомість

2 Госпел - жанр негритянської духовної християнської музики, що розвинувся у першій третині XX століття і продовжував традицію спірічуелз. 
чорношкірих, їхнє світобачення. По-друге, прибульці до міста трансформували його культуру та містян.

Дисииплінарна влада міста. Локус міста лише на перший погляд символізує багатоманітність ma гетерогенність. Як зазначає Д. Стівенсон: «Гетерогенність та багатоманітність прописані в міському пейзажі по-різному: наприклад, у вигляді та розміщенні будинків, ресторанів, реклами, парків та інших будівель й форм інфраструктури» $[12,32]$. Міські жителі через свою приналежність до різних расових, національних, етнічних, гендерних та класових груп творять багатоликість. Дослідниця слушно зауважує, що відмінність також структурує досвід та життя мешканців, вона «є причиною та маніфестацією нерівності та невигідного становища» [12, р. 32]. Багатоманітність зумовлює виникнення маргіналізованих груп. Насправді розмаїття міського локусу чітко структуроване та $€$ втіленням «дисциплінарної влади» (Фуко), що виражається найперше в існуванні окремих міських гетто чи районів компактного проживання різних расових, етнічних та національних спільнот. Місто постає і як структура пригноблення, і як локус толерування відмінності. Наприклад, у США в часи Великої міграції афроамериканці, що масово прибували на Північ, були вимушені поселятись лише в районах для чорношкірих. Незважаючи на перенаселеність

\section{СПИСОК ВИКОРИСТАНИХ ДЖЕРЕЛ}

1. Фуко М. Наглядати й карати. Народження в'язниці / Фуко Мішель; [пер. $з$ французької П. Таращук]. - Київ: Видавництво Соломії Павличко «Основи», 1998. - 391 с.

2. Штейнбук Ф. Під знаком «Саваофа», або «Там, де...» Ульяненко/ Штейнбук Фелікс. - Київ: Видавництво Дмитра Бураго, 2020.- 396с.

3. Fisher R. The Walls of Jericho / Fisher Rudolph. - With a new preface by William H. Robinson Jr. - New York: Arno Press and the New York Times, 1969. - 307 p.

4. Frazier Fr. La Bourgeoisie Noire // The New Negro: Readings on Race, Representation, and African American Culture, 1892-1938. - Ed. Henry Louis Gates, Gene Andrew Jarrett, Princeton UP, Princeton, 2007. - P. 137 - 141.

5. Griffin F. «Who Set You Flowin'?» The AfricanAmerican Migration Narrative / Griffin Farah / Oxford: Oxford University Press, 1996. - 236 p.

6. Harlem Speaks. A Living History of the Harlem Renaissance. Ed. By Cary D. Wintz. Sourcebooks, Inc., 2007. $-502 p$. «чорних» районів Нью-Йорка чи Чикаго, чорношкірі не могли вільно змінювати місце проживання, тобто порушувати межі наданого їм простору. Визначений локус проживання є однією з форм дисциплінарної влади міста, яка таким чином перетворює тіла мігрантів на «покірливі тіла». Як писав М. Фуко: «Дисципліна розпочинається передусім з розподілу індивідів у просторі» [1, с. 176]. Іншими словами, дисципліна простору обертає «плутану, безвартісну або небезпечну множинність на впорядковану множину» [1, с. 184]. Це дає змогу владі контролювати та наглядати за багатоманітністю міста. Відтак афроамериканці, що масово мігрували з Півдня з надією утекти від расизму та тілесних покарань, потрапляли на Півночі в жорстку дисциплінарну систему міста, яка неухильно контролювала їхні рухи та тіла.

Висновки. Розглянутий у статті образ Гарлема як столиці Нового Негра дає підстави стверджувати, що фізичний простір раси створювався з метою контролю за великою кількістю мігрантів, які прибували з Півдня. До формування цього типу території були залучені як економічні, так і символічні типи влади. Водночас поза увагою залишився той факт, що Гарлем як расовий простір охоплював головним чином бідний робітничий клас, у той час, коли чорношкіра буржуазія прагнула відмежуватися і тому її представники переїжджали в інші райони Нью-Йорка.

7. Haynes G. Negroes Move North / Haynes George// The Survey. - 1918. - 4 May. - P.115 -122.

8. Johnson J. Black Manhattan / Johnson James Weldon. - Knopf, New York, 1930. - 354p.

9. Lefebvre H. State, Space, World: Selected Essays. Trans. Jerald Moore, Neil Brenner, Stuart Elden / Lefebvre Henri. University of Minnesota Press, Minneapolis, 2009. - 342p.

10. Mitchell D. Cultural Geography: A Critical Introduction/Mitchell Donald. Blackwell Publishers Ltd, Oxford, 2001. - 352p.

11. Reed Ad. Class Notes: Posing As Politics and Other Thoughts on the American Scene / Reed Adolph Jr. New York, New Press, 2001. - 240p.

12. Stevenson D. Cities and Urban Cultures / Stevenson Deborah. - Open University Press, 2003. - 169 p.

13. Thurman W. The Blacker the Berry... / Thurman Wallace. - With an Introduction by Therman B. O'Daniel. — New York: The Macmillan Company, 1970. $-231 \mathrm{p}$. 


\section{REFERENCES}

1. Foucault Michel. Nahliadaty y karaty. Narodzhennia viaznytsi / Fuko Mishel; [per. z frantsuzkoi P. Tarashchuk]. - Kyiv: Vydavnytstvo Solomii Pavlychko «Osnovy», 1998.-391 c.

2. Shteinbuk F. Pid znakom «Savaofa», abo «Tam, de...» Ulianenko/ Shteinbuk Feliks. - Kyiv: Vydavnytstvo Dmytra Buraho, 2020.- 396s.

3. Fisher R. The Walls of Jericho / Fisher Rudolph. With a new preface by William H. Robinson Jr. New York: Arno Press and the New York Times, 1969. - $307 \mathrm{p}$.

4. Frazier Fr. La Bourgeoisie Noire // The New Negro: Readings on Race, Representation, and African American Culture, 1892-1938. - Ed. Henry Louis Gates, Gene Andrew Jarrett, Princeton UP, Princeton, 2007. - P. 137 - 141.

5. Griffin F. «Who Set You Flowin'?» The AfricanAmerican Migration Narrative / Griffin Farah / Oxford: Oxford University Press, 1996. — 236 p.

6. Harlem Speaks. A Living History of the Harlem Renaissance. Ed. By Cary D. Wintz. Sourcebooks, Inc., 2007. $-502 p$.
7. Haynes G. Negroes Move North / Haynes George// The Survey. - 1918. - 4 May. - P.115 -122.

8. Johnson J. Black Manhattan / Johnson James Weldon. - Knopf, New York, 1930. $-354 \mathrm{p}$.

9. Lefebvre H. State, Space, World: Selected Essays. Trans. Jerald Moore, Neil Brenner, Stuart Elden / Lefebvre Henri. University of Minnesota Press, Minneapolis, 2009. - 342p.

10. Mitchell D. Cultural Geography: A Critical Introduction / Mitchell Donald. Blackwell Publishers Ltd, Oxford, 2001. - 352p.

11. Reed Ad. Class Notes: Posing As Politics and Other Thoughts on the American Scene / Reed Adolph Jr. New York, New Press, 2001. - 240p.

12. Stevenson D. Cities and Urban Cultures / Stevenson Deborah. - Open University Press, 2003. - 169 p.

13. Thurman W. The Blacker the Berry... / Thurman Wallace. - With an Introduction by Therman B. O'Daniel. — New York: The Macmillan Company, 1970. $-231 \mathrm{p}$.

\title{
REAL AND IMAGINED SPACES OF HARLEM AT THE BEGINNING OF THE $20^{\text {TH }}$ CENTURY
}

\section{Mariya Shymchyshyn}

https://orcid.org/0000-0003-4980-3296

mshymchyshyn@yahoo.com

Doctor of Sciences (Philology), Professor, Head of the Department of Literary Theory and World

Literature named after Professor V.I. Fesenko, Kyiv National Linguistic University

\begin{abstract}
At the beginning of the $20^{\text {th }}$ century, the urgency of the regime of a new black collective racial identity caused the formation of a dominant fictional image of Harlem as a space where "racial men" live. Therefore dominant fictional Harlem spaces belonged to the corporate discourse of "new black race identity". To some extent, Harlem was withdrawn from nature and reality only to symbolize at once the absent and present transcendent reality of race. It is important in the geocritical investigation of fictional Harlem spaces to figure out the ways it limited the collectivity of the New Negro and prescribed it according to the racial agenda of that time. Multiple points of view help to avoid fixing the geographical referent in a monologic narrative of racial rhetoric. The spectrum of individual representations of Harlem leads not only to grasp its diversity and permanent performativity but opens new horizons in understanding the way of constructing racial collectivity.

At fin de siècle Harlem became the capital of the New Negro and the space of coining a new black subjectivity. It lured colored people from all over the world and homogenized them into the monolithic black urban collectivity. Its territory expanded rapidly because of the growing black population. A closer look at the fictional representations of Harlem disclaims the long-established idea of its homogeneity and shows that class stratification defined the nature of this racial milieu. Nevertheless, this fact was mostly neglected, because, of the idea that black collectivity belongs to the poor working class.

The racial frame of milieu limits the notion of space per se, which is at once unified and fragmented, homogeneous and divided. Injecting the geocritical perspective into the study of fictional and real Harlem will help not only to underline its role in homogenizing different groups of people, who came from such distinct places as Jamaica, the Dominican Republic, Barbados, and the South of the US into one black collective identity, but also to verbalize its diversity, multidimensional character, and distinct individual features.
\end{abstract}

Key words: race; Harlem; space; class; geocriticism. 